\title{
Influence of welding speed on the melting efficiency of Nd:YAG laser welding
}

\author{
Tadamalle, A.P. ${ }^{a,}{ }^{*}$, Reddy, Y.P. ${ }^{a}$, Ramjee, E. ${ }^{b}$, Reddy, V.K. ${ }^{b}$ \\ ${ }^{a}$ Department of Mechanical Engineering, Sinhgad College of Engineering, Vadgaon, Pune, India \\ ${ }^{b}$ Department of Mechanical Engineering, Jawaharlal Nehru Technological University, Kukatpally, Hyderabad, India
}

\section{A B S T R A C T}

Melting efficiency is one of the more important measurable parameters in laser welding when assessing the performance of a process. This paper aims to study the effects of speed on the melting efficiency and energy transfer efficiency of Nd:YAG laser welding process. The weld bead on a 304L austenitic stainless steel sheet is created by varying the welding speed. The weld samples are cut in the transverse direction by using electric discharge machining, and the cross-section is prepared for metallographic inspection. The cross-sectional dimensions and beads length are measured by using an optical microscope and image analyzer. A methodology is proposed for estimating the weld pool volume from experimental data and a generalised equation for predicting the melting efficiency and energy transfer efficiency is developed. The results obtained by the proposed method have reasonably good agreement with the models proposed by various researchers. The outcome of the result shows the significant influence of welding speed on melting efficiency and energy transfer efficiency in welding of austenitic stainless steel thin sheets. It will be seen from results that one can select appropriate welding speed and processing conditions to obtain desired melting efficiency.
\end{abstract}

\section{ARTICLE INFO}

Keywords:

$\mathrm{Nd}$ :YAG laser welding

Melting efficiency

Weld pool volume

Energy transfer efficiency

Heat affected zone

*Corresponding author: aptadmalle.scoe@sinhgad.edu (Tadamalle, A.P.)

Article history:

Received 22 May 2014

Revised 7 August 2014

Accepted 15 August 2014 


\section{References}

[1] Fuerschbach, P.W., Eisler, G.R. (1999). Effect of very high travel speed on melting efficiency in laser beam welding, SAE International Journal of Materials and Manufacturing, Vol. 108, No. 5, 824-829, doi: 10.4271/1999-01-0996.

[2] Lankalapalli, K.N., Tu, J.F., Gartner, M. (1996). A model for estimating penetration depth of laser welding processes, Journal of Physics D: Applied Physics, Vol. 29, No. 7, 1831-1841, doi: 10.1088/0022-3727/29/7/018.

[3] Tadamalle, A.P., Reddy, Y.P., Ramjee, E. (2013). Influence of laser welding process parameters on weld pool geometry and duty cycle, Advances in Production Engineering \& Management, Vol. 8, No. 1, 52-60, doi: 10.14743/ apem2013.1.153.

[4] Walsh, C.A. (2002). Laser welding - literature review, Materials Science and Metallurgy Department, University of Cambridge, England, from http://www.msm.cam.ac.uk/phase-trans/2011/laser_Walsh_review.pdf, accessed August, 21, 2014.

[5] Pépe, N., Egerland, S., Colegrove, P.A., Yapp, D., Leonhartsberger, A., Scotti, A. (2011). Measuring the process efficiency of controlled gas metal arc welding processes, Science and Technology of Welding \& Joining, Vol. 16, No. 5, 412-417, doi: 10.1179/1362171810Y.0000000029.

[6] Chang, W.S., Na, S.J. (2002). A study on the prediction of the laser weld shape with varying heat source equations and the thermal distortion of a small structure in micro-joining, Journal of Materials Processing Technology, Vol. 120, No. 1-3, 208-214, doi: 10.1016/S0924-0136(01)00716-6.

[7] Fuerschbach, P.W., MacCallum, D.O. (1995). Variation of laser energy transfer efficiency with weld pool depth, In: Proceedings of $14^{\text {th }}$ International Congress on the Applications of Lasers and Electro-Optics, San Diego, California, USA, 493-497.

[8] Unocic, R.R., DuPont, J.N. (2004). Process efficiency measurements in the laser engineered net shaping process, Metallurgical and Materials Transactions B, Vol. 35, No. 1, 143-152. doi: 10.1007/s11663-004-0104-7.

[9] Fuerschbach, P.W. (1995). A dimensionless parameter model for arc welding process, In: Trends in Welding Research: Proceedings of the $4^{\text {th }}$ International Conference, Gatlinburg, Tennessee, USA, 493-497.

[10] DuPont, J.N., Marder, A.R. (1995). Thermal efficiency of arc welding processes, Supplement to the Welding Journal, 406-416, from http://www.aws.org/wj/supplement/WJ_1995_12_s406.pdf, accessed August 21, 2014.

[11] Fuerschbach, P.W., Eisler, G.R. (2002). Effect of laser spot weld energy and duration on melting absorption, Science and Technology of Welding and Joining, Vol. 7, No. 4, 241-246, doi: 10.1179/136217102225004293.

[12] Nath, A.K., Sridhar, R., Ganesh, P., Kaul, R. (2002). Laser power coupling efficiency in conduction and keyhole welding of austenitic stainless steel, Sadhana, Vol. 27, No. 3, 383-392, doi: 10.1007/BF02703659.

[13] Tzeng, Y.-F. (2000). Process characterisation of pulsed Nd:YAG laser seam welding, The International Journal of Advanced Manufacturing and Technology, Vol. 16, No. 1, 10-18, doi: 10.1007/PL00013126.

[14] Christensen, N., Davies, V. de L., Gjermundsen, K. (1965). Distribution of temperature in arc welding, British Welding Journal, Vol. 12, No. 2, 54-75.

[15] Klimpel, A., Rzeźnikiewicz, A., Janik, Ł. (2007). Study of laser welding of copper sheets, Journal of Achievements in Materials and Manufacturing Engineering, Vol. 20, No. 1-2, 467-470.

[16] Norris, J.T., Robino, C.V., Perricone, M.J., Hirschfeld, D.A. (2010). Development of a time-resolved energy absorption measurement technique for laser beam spot welds, Welding Journal, Vol. 89, No. 4, 75s-81s.

[17] Wang, R., Lei, Y., Shi, Y. (2011). Numerical simulation of transient temperature field during laser keyhole welding of 304 stainless steel sheet, Optics \& Laser Technology, Vol. 43, No. 4, 870-873, doi: 10.1016/j.optlastec. 2010.10.007.

[18] Patschger, A., Bliedtner, J., Bergmann, J.P. (2013). Approaches to increase process efficiency in laser micro welding, Physics Procedia, Vol. 41, 592-602, doi: 10.1016/j.phpro.2013.03.121.

[19] Bergmann, J.P., Patschger, A., Bastick, A. (2011). Enhancing process efficiency due to high focusing with high brightness lasers - applicability and constraints, Physics Procedia, Vol. 12, Part A, 66-74, doi: 10.1016/i.phpro. 2011.03.009.

[20] Mladenov, G., Vutova, K., Wojcicki, S. (1998). Experimental investigation of the weld depth and thermal efficiency during electron beam welding, Vacuum, Vol.51, No. 2, 231-233, doi: 10.1016/S0042-207X(98)00165-1.

[21] Kim, T.H., Albright, C.E., Chiang, S. (1990). The energy transfer efficiency in laser welding process, Journal of Laser Applications, Vol. 2, No. 1, 23-28, doi: 10.2351/1.4745249.

[22] Tu, J.F., Paleocrassas, A.G. (2010). Low speed laser welding of aluminium alloys using single-mode fiber lasers, In: Stone, X.A. (ed.), Laser Welding, InTech, 47-76, doi: 10.5772/9857.

[23] Forsman, T., Powell, J., Magnusson, C. (2001). Process instability in laser welding of aluminum alloys at the boundary of complete penetration, Journal of Laser Applications, Vol. 13, No. 5, 193-198, doi: 10.2351/1.1404414.

[24] Hamadi, O.A., Khashan, K.S. (2008). Modeling of the preheating effect on keyhole laser welding efficiency, Iraqi Journal of Applied Physics Letters, Vol. 1, No. 1, 10-15.

[25] Greses, J., Barlow, C.Y., Hilton, P.A., Steen, W.M. (2003). Effects of different gas environments on $\mathrm{CO}_{2}$ and Nd:YAG laser welding process efficiencies, In: SPIE Proceedings: First international Symposium on High-Power Laser Macroprocessing, Osaka, Japan, 257-263, doi: 10.1117/12.486500. 


\title{
Vpliv hitrosti varjenja na talilni učinek pri varjenju z laserjem Nd:YAG
}

\author{
Tadamalle, A.P. ${ }^{a}{ }^{,}$, Reddy, Y.P. ${ }^{a}$, Ramjee, E. ${ }^{b}$, Reddy, V.K. ${ }^{b}$ \\ a Department of Mechanical Engineering, Sinhgad College of Engineering, Vadgaon, Pune, India \\ ${ }^{b}$ Department of Mechanical Engineering, Jawaharlal Nehru Technological University, Kukatpally, Hyderabad, India
}

\section{POVZETEK}

Talilni učinek je $\mathrm{z}$ vidika vrednotenja učinkovitosti postopka eden izmed najbolj pomembnih merljivih parametrov pri varjenju z laserjem. Namen pričujočega članka je proučiti vpliv hitrosti varjenja na talilni učinek in izkoristek prenosa energije pri varjenju z laserjem Nd:YAG. Varek je bil narejen na avstenitnem nerjavnem jeklu 304L, in sicer s spreminjanjem hitrosti varjenja. Vzorci so bili nato prerezani v prečni smeri z uporabo postopka elektroerozije, preseki pa so bili pripravljeni za metalografski preizkus. Z optičnim mikroskopom in analizatorjem slik so bile izmerjene dimenzije preseka in dolžine varkov. $V$ članku je predlagana metodologija za oceno volumna taline zvara iz eksperimentalnih podatkov, prav tako pa sta podani splošni enačbi za napovedovanje talilnega učinka in izkoristka prenosa energije. Dobljeni rezultati se precej dobro ujemajo z modeli, ki so jih predlagali drugi raziskovalci. Rezultati so pokazali signifikantni vpliv hitrosti varjenja na talilni učinek in izkoristek prenosa toplote pri varjenju tanke pločevine iz avstenitnega nerjavnega jekla. Rezultati omogočajo tudi izbiro ustrezne hitrosti varjenja in procesnih pogojev za doseganje želenega talilnega učinka.

\section{PODATKI O ČLANKU}

Ključne besede:

$\mathrm{Nd}: Y A G$ lasersko varjenje

Talilni učinek

Volumen taline vara

Izkoristek prenosa energije

Temperaturno vplivna cona

*Kontaktna oseba: aptadmalle.scoe@sinhgad.edu (Tadamalle, A.P.)

Zgodovina članka:

Prejet 22. maja 2014

Popravljen 7. avgusta 2014

Sprejet 15. avgusta 2014 